\title{
Transakcyjny model dzieła muzycznego w późnej twórczości Mortona Feldmana
}

\author{
Damian Binkowski \\ Wydział Filologiczny \\ Uniwersytet Gdański \\ damian--binkowski@wp.pl
}

\begin{abstract}
Abstrakt
Celem artykułu jest wykazanie otwartego charakteru późnych utworów Mortona Feldmana, mimo zapisania ich w tradycyjnej formie. Analizy umieszczono w szerokim kontekście, wliczając w to zarówno muzykę, sztukę, literaturę piękną, jak i naukę.
\end{abstract}

Słowa kluczowe: Morton Feldman; dzieło otwarte; model transakcyjny; czas w muzyce; nielinearność w muzyce.

Stuchajac utworów Feldmana, czujemy, jak głęboko rozumiat malarstwo Rothki ${ }^{1}$.

(Rothko 2013: 152)

Umberto Eco stwierdził w Dziele otwartym istnienie zbieżności między formą dzieła sztuki i sposobem jego kształtowania a stanem świadomości oraz poglądami na budowę świata czy strukturę rzeczywistości funkcjonującymi w kulturze danej epoki. Zasada ta obowiązuje również w czasach utraty wiary w pojmowaną realistycznie i fundamentalistycznie obiektywność - w ideał bezstronnego, wolnego od wszelkich perspektyw oglądu wiecznie stabilnej rzeczywistości, dostępnej poza strukturami stworzonymi przez człowieka i jego umysł. Wobec świata, gdzie nie ma jednego, jednoznacznego, wyczerpującego i nadrzędnego rozumienia danej rzeczy, gdzie niemożliwe stało się ostateczne i całościowe przedstawienie zjawisk pozbawionych ciągłości - świata, którego nie warunkują już reguły tworzące niegdyś jego metafizyczne rusztowania, funkcję metafory epistemologicznej może przyjąć sztuka otwarta (Eco 1994: 169-170).

\footnotetext{
${ }^{1}$ Cytaty obcojęzyczne, o ile nie zostały zaopatrzone w nazwisko thumacza (por. LITERATURA), podane są w przekładzie autora.
} 
Dzieła otwarte stanowią ważną część dorobku twórczego Mortona Feldmana, kompozytora amerykańskiego, który wraz z Earle’em Brownem i Christianem Wolffem należał do awangardowej szkoły kompozytorskiej, tak zwanej szkoły nowojorskiej, skupionej wokół Johna Cage'a. Feldman był pionierem muzyki niezdeterminowanej pod względem wykonania. Jego pięć Projections (1950-1951), cykl utworów o różnej obsadzie (I - wiolonczela; II - flet, trąbka, fortepian, skrzypce, wiolonczela; III - dwa fortepiany; IV - skrzypce i fortepian; V - trzy flety, trąbka, dwa fortepiany i trzy wiolonczele), to najprawdopodobniej pierwsze w historii partytury graficzne. Chcąc wyzwolić następstwa dźwiękowe z więzi składniowych, kompozytor wysuwa tu na plan pierwszy barwę, artykulację i dynamikę, marginalizując jednocześnie aspekt diastematyczny. Dostępny zakres wysokości podzielił na rejestry: niski, środkowy i wysoki, pozostawiając woli wykonawcy zarówno doprecyzowanie ich rozpiętości, jak i wybór tonów wydobywanych z instrumentu. Partytury kolejnych ogniw cyklu wypełniają zdawkowe, a jednocześnie wieloznaczne symbole graficzne. Partie poszczególnych instrumentów zostały zapisane w przedziałach wyznaczonych przez horyzontalne linie ciągłe oraz przerywane linie pionowe, rozmieszczone regularnie i w ten sposób określające stałe następstwo jednostek czasu (wyjątek stanowi pierwszy z utworów cyklu, gdzie każda z warstw odpowiada innemu sposobowi artykulacji). Wszystkie warstwy instrumentalne są zsynchronizowane. W ich obrębie zostają umieszczone prostokąty, których długość wskazuje czas trwania zdarzeń dźwiękowych, a położenie: w poziomie - komunikuje czasowe rozmieszczenie dźwięków; w pionie wyznacza wysokość relatywną, a więc jedynie rejestr, w jakim zlokalizowane są dźwięki wydobywane z poszczególnych instrumentów. Symbole literowe wpisane wewnątrz prostokątów informują o artykulacji skrzypiec i wiolonczeli $(\mathrm{A}=\operatorname{arco}, \mathrm{P}=$ pizzicato, mały romb = flażolet). Cyfry arabskie wskazują liczbę dźwięków wydobywanych jednocześnie (por. Nyman 2011: 73; Skowron 1995: 294-296).

Jednak aż do momentu skomponowania przez Feldmana utworu Two Pianos, czyli do 1957 roku, jego koncepcja czasu muzycznego nadal zakładała istnienie regularnego pulsu metrycznego, ograniczającego ekspresję rytmiczną wykonawcy:

Ten aspekt mojej muzyki graficznej zawsze mnie niepokoił. Nie mogłem zrozumieć, i nadal nie mogę, jak mogłem zupełnie zrezygnować z kontroli wysokości dźwięku, a nie z tej rytmicznej osnowy, w której się on wydarza (Feldman 1972: SLR315).

Sposób na otwarcie czasu znaleziono przypadkiem. Przed występem Johna Cage'a i Davida Tudora w Harvardzie, gdzie wykonany miał zostać dedykowany im utwór na dwa fortepiany Feldmana ${ }^{2}$, okazało się, że instrumenty zastane na miejscu są w bardzo złym stanie technicznym. Z najbardziej złożonych rytmów, niemożliwych do zrealizowania w takich warunkach, postanowiono zrezygnować, inne pianiści mieli tylko zasygnalizować. Ich interpretacja była na tyle niedoskonała, by pobudzić wyobraźnię autora kompozycji. Po powrocie do Nowego Jorku, mając w pamięci to - jak je określił - „spaczone wykonanie”, Feldman wprowadza pełną indeterminację rytmiczną (free-rhythm notation) w utworach,

\footnotetext{
${ }^{2}$ Prawdopodobnie Two Pieces for Two Pianos (1954).
} 
w których „tempo i trwania miały zależeć od charakteru substancji akustycznej danego dźwięku i sposobu, w jaki wybrzmiewa; bardziej od czasu pomiędzy momentami ataku i zaniku dźwięku niż rytmu" (Feldman 1972: SLR315, 1973 SLR320).

Dalszą konsekwencją tego odkrycia był utwór Piece for Four Pianos (1957), gdzie każdy $\mathrm{z}$ wykonawców gra to samo, lecz we własnym tempie, w rezultacie czego powstaje zwielokrotniony, quasi-polifoniczny efekt brzmieniowy - rodzaj mikroecha, wywołanego przez desynchronizację poszczególnych partii instrumentalnych, wywołującą subtelne przesunięcia fazowe pomiędzy momentami zaatakowania tego samego dźwięku przez poszczególnych wykonawców oraz pomiędzy momentami jego wybrzmienia. Feldman powracał do tego chwytu w dziełach takich jak np. Piano Three Hands (1957), Piano Four Hands (1958), Durations I-V (1960-1961), The Swallows of Salagan (1961), For Franz Kline (1962) czy False Relatioships and the Extended Ending (1968) (por. Bland 1980: 455).

Ważne miejsce wśród nich zajmuje cykl Durations na różne zestawy instrumentów (I [1960] - na flet altowy, fortepian, skrzypce i wiolonczelę; II [1960] - na wiolonczelę i fortepian; III [1961] - na skrzypce, tubę i fortepian; IV [1961] - na skrzypce, wiolonczelę i wibrafon; V [1961] - na skrzypce, wiolonczelę, róg, wibrafon, harfę i fortepian lub czelestę). Kompozytor łączy tu swobodne ujęcie trwań i relacji wertykalnych z precyzyjnym zapisem pozostałych parametrów, podsumowując swoje eksperymenty oraz poszukiwania strukturalne i notacyjne z lat 50. (por. Skowron 1995: 297).

Pierwszej z czterech miniaturowych kompozycji, z jakich składa się trzecia część cyklu, przyjrzała się polska muzykolożka, Dorota Maciejewicz:

Kompozycja pierwsza (podobnie jak pozostałe) skonstruowana jest z szeregu wertykalnych brzmień pozbawionych rytmicznego dookreślenia. Co więcej, dowolność wykonania jest wspomagana przez liczne zastosowanie fermat. W miarę jak utwór trwa, słyszy się, że nie posiada on żadnej linearnej struktury, a jedynie brzmienia zmieniające się jak w kalejdoskopie. Brzmienia wydają się poddane jedynie idei następstwa izolowanych, wertykalnych konfiguracji pozbawionych jakichkolwiek powiązań. Kompozycję tworzą następstwa bardziej lub mniej gęstych momentów (Maciejewicz 2000: 101).

W utworze Durations III $n r 1$ Maciejewicz dostrzegła też aspekt przedsymboliczny, łączony w teorii Julii Kristevej z pojęciem modalności semiotycznej, która chronologicznie i logicznie poprzedza modalność symboliczną, określaną przez porządek językowy, uwarunkowany społecznie i ustanawiający zarówno znak, jak i reguły składni. Przedjęzykowa modalność semiotyczna została utożsamiona przez Kristevą z platońską chora, gromadzącą nieustający strumień procesów pierwotnych, uwarunkowanych przez popędy podmiotu. Są one niezbędne dla powstania znaku lingwistycznego, a jednak niewystarczające do jego wyartykułowania. Wyłaniają się z nich płynne i efemeryczne wzory, pozbawione stabilnej tożsamości, wytwarzane i jednocześnie negowane, o statusie przed-znaczeń i przed-znaków, tymczasowych i wielorakich. Maciejewicz zauważyła obecność podobnych procesów w muzyce Feldmana, wiążąc je między innymi z kategorią wzoru (pattern), sformułowaną przez kompozytora w drugiej połowie lat 70. i opisującą poetykę 
dzieł z ostatniego okresu jego twórczości. Wzory tego rodzaju nie pełnią funkcji strukturalnej. Nie przyczyniają się też do ustanowienia jakiejkolwiek hierarchii ani porządku formalnego. Mają charakter prowizoryczny. W toku utworu są decentralizowane, neutralizowane i negowane, by uniemożliwić ustalenie jakiejkolwiek zasady, mimo że początkowo taką możliwość zasugerowano. Są zbyt niedookreślone, a ich tożsamość jest zbyt płynna, ulegająca rozmyciu, by wyartykułować zintegrowany znak. Kompozytor dąży do utrzymania muzyki w stanie prelingwistycznym, by nie przekroczyć granicy modalności symbolicznej (Maciejewicz 1999: 132-133, 2000: 101-107). Feldmanowi udaje się więc osiągnąć rezultat, jaki chciał uzyskać w swoich utworach Samuel Beckett, zmierzający do tej samej granicy z „,terytorium” języka.

Mimo świadomości, że pisarstwo skazywało go na język, na posługiwanie się nim, Beckett nie ufał mu. Był pod tym względem bliski Cage’owi, któremu mówienie sprawiało podobną trudność, bo słowa, zmuszając go do podporządkowania się zasadom logicznym i gramatycznym, pozbawiały go tym samym możliwości swobodnego wyrażania myśli, ale też narzucały ograniczenia percepcji zarówno zjawisk fizycznych, jak i psychicznych (por. Kutnik 1997: 169). Zbieżność językowych problemów obu twórców widoczna jest u Becketta zwłaszcza w powieści Nienazywalne z 1953 roku. Irlandzki noblista nie bez powodu zatytułował ją pierwotnie Beyond Words (Poza słowami). Wyczuwa się tu istnienie pewnego, bliżej nieokreślonego centrum, które umożliwia (a przynajmniej sprawia takie wrażenie) ogólną orientację: o czym się mówi, gdzie się mówi, kto mówi. Są to jednak zaledwie pozory narracji powieściowej, przyjmujące postać monologu rozwijanego wielokrotnie wbrew zasadzie niesprzeczności logicznej i pogrążanego w procesie demontażu spójności tekstu. Sformułowany sens po chwili rozpada się - jak w umeblowanym pokoju, w którym panuje stan nieważkości. Rozpoznaje się sprzęty, ale trudno znaleźć jakiś punkt odniesienia, kierunek - gdzie jest góra, gdzie jest dół (Kędzierski 1990: 363). Jawnie antylogocentryczne jest słuchowisko Words and Music z 1961 roku, na zlecenie Becketta ponownie opracowane muzycznie przez Feldmana w 1986 roku. Libretto do opery Neither, napisane przez Becketta dla Feldmana w 1976 roku, również wskazuje na pozajęzykowe formy świadomości i rozumienia, jakie usiłuje wyrazić przy pomocy pojęcia „niewysławialnego domu” o właściwościach ,ja”, będącego „neither”.

Podmiotowa jaźń, świadomość, samoświadomość, czynnik wewnętrzny były eksplorowane konsekwentnie w kolejnych dziełach pisarza. Począwszy od Końcówki coraz większe znaczenie zyskują przedstawienia sytuacji psychologicznych, pozbawionych odniesień do rzeczywistości zewnętrznej, w tym również do rzeczywistości społecznej. Bohater Filmu, chcąc symbolicznie odciąć się od świata zewnętrznego (por. Libera 1981: 210), ucieka z ulicy do mieszkania, do pokoju. Zamyka okno i zasłania lustro. Pozbywa się zastanych na miejscu zwierząt i niszczy fotografie. Beckett thumaczył, że motywem takiego zachowania była chęć ucieczki

od wszelkiego postrzegania, od wszystkich, którzy go postrzegają, włączając Boga (zdejmuje ze ściany obraz). Ale nie może uciec od postrzegania samego siebie. To jest idea 
biskupa Berkeleya, filozofa irlandzkiego i idealisty «Być to jest być postrzeganym» (Esse est percipi). Jeśli człowiek pragnie przestać istnieć, musi przestać być postrzegany (Rosset 1996: 82).

Od końca lat 60. można mówić już o „Ich-Drama” Becketta oraz wykrystalizowaniu formuły teatru wewnętrznego: świadomość jednostkowa, przestrzeń subiektywna umysłu, „wnętrze głowy” stają się areną akcji scenicznej. Proza irlandzkiego noblisty pisana w tym samym okresie niczym nie ustępuje jego twórczości teatralnej. Realizm zostaje sprowadzony w niej do poziomu zerowego. Celem Becketta nie jest już ,przedstawienie człowieka w ruchu, tylko r u ch u w c złow i e k u " (Kędzierski 1996: 110), ujawnionego w samopoznaniu, a jednak wyznaczającego perspektywę, z jakiej podmiot postrzega otaczającą go rzeczywistość. Świat wewnętrzny jaźni staje się przedmiotem jej poznania, a więc - paradoksalnie - światem zewnętrznym względem podmiotu; natomiast świat zewnętrzny, o którym można by sądzić, że istnieje poza umysłem (poza czaszką), okazuje się światem wewnętrznym, a przynajmniej zapośredniczonym przez wewnętrzny świat percepcji, dzięki której jest w ogóle podmiotowi dostępny:

[...] nasza pospolita percepcja napotyka jedynie pospolite zjawiska. Pozbawienie danego przedmiotu całej jego wewnętrznej zmienności nie przekreśla tego, iż dalej zależy on od jakiegoś podmiotu, ten zaś nie daje się już tak zredukować. Obserwator zaraża to, co obserwuje, swoją własną zmiennością (Beckett 1983: 79).

Można odnieść wrażenie, że świat widziany oczami Becketta jest jak The 2000 Sculpture, czyli minimalistyczna rzeźba stworzona w 1992 roku przez ucznia Cage'a, Waltera de Marię, złożona z dwóch tysięcy białych, gipsowych równoległościanów, zestawionych na podłodze w równoległych rzędach. Gdy chodzi się dookoła The 2000 Sculpture (a innej możliwości nie ma), okazuje się, że w zależności od padania światła i położenia patrzącego względem rzeźby, gipsowe elementy łączą się w linie rozchodzące się w różnych kierunkach. Nieunikniona zmiana punktu widzenia wywołuje zmianę ich aspektu, sprawiając, że - jak opisał je Wolfgang Welsch - „w jednej chwili wyglądają jak węże, w następnej jak fale, łańcuchy czy jak wydmy" (Welsch 2005: 152). Statyczne niczym przedmiot, o którym Beckett wspomina w zacytowanym powyżej fragmencie ze swego Prousta, dzieło to również jest przedmiotem zależnym od jakiegoś podmiotu: mimo że „gipsowe elementy leżą na podłodze nieporuszone - perceptualnie dzieło jest w stanie ciągłego ruchu i zmiany" (Welsch 2005: 153). Zgodnie z maksymą esse est percipi Berkeleya, inspirującą powstanie Filmu Becketta, rzeźba ta dosłownie - jest, istnieje, ponieważ jest postrzegana. Welsch pisał:

W tym sensie uważam tę rzeźbę za paradygmatyczne dzieło aisthesis, a więc percepcji. Objawia się ono tylko poprzez percepcję i percepcja ta, wykraczająca poza obserwację tego, co faktycznie dane, generuje dzieło. Dzieła więc nie ma, jest tylko materiał - nasza percepcja pozwala dziełu się narodzić (Welsch 2005: 152).

Pokrewny sposób istnienia przypisał Welsch wybranym utworom z literatury muzycznej XX wieku. Znalazł się wśród nich Thirteen Cage'a, z tego samego, co opisana wyżej rzeźba de Marii, 1992 roku. W trakcie słuchania Thirteen „stajemy się jego częścią, 
wnikamy w ciąg dźwięków, by w końcu płynąć wraz z nim - jako części, nie obserwatorzy tego, co słyszymy" (Welsch 2005: 156). Dość podobna zdaniem niemieckiego filozofa jest też starsza o kilkanaście lat kompozycja Feldmana zatytułowana Piano and Orchestra (1975) (Welsch 2005: 156). Opinię tę zdają się potwierdzać spostrzeżenia Catherine Laws. Według niej Feldman pozbawia odbiorców możliwości obiektywnego, zewnętrznego spojrzenia na dzieło i umieszcza ich jakby wewnątrz aktualnie słuchanego utworu, wyłaniającego się w dynamicznym, pozbawionym stabilności, a jednak wewnętrznym doświadczeniu jego percepcji. Tego samego doświadczają zdaniem Laws odbiorcy dzieł Becketta (Laws 1988: 84).

Właściwości podobne do tych wiązanych ze wspomnianymi dziełami zostały przypisane też rzeczywistości przez twórców koncepcji poznania łączonej przez Eco z tak zwaną metodologią transakcyjną, stworzoną w psychologii na bazie twierdzeń Johna Deweya. Czynnikiem kształtującym postrzeganie są wspomnienia doświadczeń przeszłych, będące zaledwie próbą rekonstrukcji sytuacji percepcyjnych zaistniałych wcześniej. Informacje rejestrowane w pamięci człowieka, inaczej niż w przypadku pamięci pendrive'a, różnią się od informacji wydobywanych z niej. Przywołanie pamięciowe - jako proces dynamiczny, odbywający się w czasie przy aktywnym udziale podmiotu - zostaje włączone do aktualnej percepcji w reakcji na informacje dostarczane przez zmysły. Tym samym umożliwia uformowanie ich w doświadczeniu transakcji psychologicznej, prowadzącej do zespolenia odbiorcy danych zmysłowych ze światem faktycznie ukonstytuowanym w akcie postrzeżeniowym. W takich warunkach trudno mówić o istnieniu izomorfizmu struktury bodźców i struktur psychofizjologicznych, postulowanym przez gestaltystów, który ma gwarantować bezpośrednie rozpoznanie zjawisk istniejących obiektywnie. Izomorfizmu nie potwierdziły też badania empiryczne. Procesy poznawcze okazują się co najwyżej hipotezami lub przewidywaniami formułowanymi na podstawie indywidualnych doświadczeń jednostki przeżytych przez nią wcześniej. Dlatego, pomimo istnienia konstant percepcyjnych, interpretacje rzeczywistości i elementów tworzących jej strukturę mogą różnić się, uwzględniając zaledwie wybrane aspekty przedmiotów percypowanych przez podmiot, zależnie od jego dyspozycji (por. Eco 1994: 62-63, 137-139; Jarzębska 2002: 261-263; Maruszewski 2001: 17, 49).

Model percepcji, jaki wyłania się z tych założeń, pozwala - zdaniem Eco - w pełni zobrazować sposób istnienia dzieła sztuki, zdefiniowany przez niego jako otwarcie drugiego stopnia, gdzie uwzględnienie zarysowanych powyżej procesów psychicznych zostaje zamierzone. Do takiego stanu dążyła jego zdaniem poetyka informelu, a wraz z nią malarstwo twórców ekspresjonizmu abstrakcyjnego ze szkoły nowojorskiej (Eco 1994: 87, 142-190). Artyści wywodzący się z niej - jak Philip Guston, Franz Kline, Willem de Koonig, Barnett Newman, Robert Motherwell, Jackson Pollock, Mark Rothko czy Clyfford Still - oddziaływali z kolei bardzo silnie na Feldmana ${ }^{3}$.

\footnotetext{
${ }^{3}$ Ich wpływ miał być nawet większy niż któregokolwiek z kompozytorów (Kopstick-Ames 1996: 99). O Gustonie, u którego w latach 40. ubiegłego wieku studiował malarstwo, Feldman pisał, że to właśnie dzięki niemu
} 
Świat widziany oczami psychologów transakcyjnych posiada też cechy przypisywane przez Marshalla McLuhana obrazowi telewizyjnemu oraz sposobowi, w jaki odbywa się jego percepcja, w której - z powodów fizjologicznych - może być uwzględnione zaledwie kilkadziesiąt z milionów małych punktów wyświetlanych na powierzchni ekranu. O ich wyborze, ale też o sposobie konfiguracji i integracji wrażeń sensorycznych, jakich dostarczają, decyduje (nieświadomie) telewidz. Oglądając ten sam program telewizyjny, każdy z odbiorców, wyposażony w struktury poznawcze uwarunkowane przez doświadczenie indywidualne, będzie widział co innego. Obraz docierający do nich jest bowiem niepełny, wymagający doprecyzowania, a w konsekwencji - odwołania się do wyobraźni (McLuhan 2001: 347-348, 402). Granice pomiędzy jej wytworami a danymi zmysłowymi dostarczanymi przez kineskop ulegają zatarciu. McLuhan twierdził nawet, że oglądając telewizję „nie patrzymy na ekran; to on patrzy na nas” (McLuhan 2001: 241). W taki sam sposób Feldman wyraził się o płótnach swoich przyjaciół - Rothki i Gustona: ,to nie my patrzymy na obraz, lecz obraz patrzy na nas" (Feldman 1985: 108). Płótna szkoły nowojorskiej, których strukturę Eco określił jako niejasną, a wymowę - jako nieokreśloną, posiadają bowiem walory obrazu telewizyjnego, a więc obrazu o niskiej wyrazistości, nieostrego i rozmytego, jak scharakteryzował go McLuhan (Eco 1994: 279; McLuhan 2001: 189, 348). W obu przypadkach obraz nie jest mechanicznie odwzorowywany, lecz aktywnie konstruowany w umysłach odbiorców, co Eco opisuje w kategoriach transakcji psychologicznej, natomiast McLuhan łączy z uwarunkowanym kulturowo modelem percepcji, określonym przez niego mianem słuchowo-dotykowego (McLuhan 2001: 225, 378).

McLuhan łączył powstanie abstrakcjonizmu w sztuce z nastaniem epoki elektrycznej. Gdy elektryczność opanowała środowisko mechaniczne wytworzone w epoce druku, które „rozgrzewało” oczy do czerwoności kosztem innych zmysłów, zimna kultura słuchowodotykowa zaczęła wypierać gorącą kulturę wizualną. Przełomowe według badacza okazało się wynalezienie telegrafu, kiedy zahamowano tendencję do zwiększania oderwania przekazu od autora i obiektywizmu tekstu, a w konsekwencji - do podziału świata na zewnętrzny i wewnętrzny, ku czemu technika ludzka skłaniała się od czasu poznania pisma fonetycznego. Do drastycznych zmian proporcji natężeń poszczególnych zmysłów, by w końcu pozbawić wzrok jego supremacji, doprowadzić miała telewizja, czyli kolejny elektryczny środek przekazu, który tylko pozornie jest wizualny, a w rzeczywistości jest słuchowo-dotykowy, tak jak chińskie pismo ideograficzne, malarstwo, ale też odczuwanie czasu. Elektryczność ma bowiem więcej wspólnego z mentalnością wschodnią niż zachodnią (de Kerckhove 2001: 131).

został artystą (Feldman 2001: 1). Nazwiska malarzy ze szkoły nowojorskiej pojawiają się w tytułach dedykowanych im utworów Feldmana, jak: For Franz Kline (1961), Piano Piece (to Philip Guston) (1963), De Koonig (1963), Rothko Chapel (1971) czy For Philip Guston (1984). 
Z punktu widzenia piśmiennego przedstawiciela zachodniej kultury wizualnej przedmioty nie wytwarzają czasu, lecz są w nim umieszczane jak w klatce czy w pojemniku i dopasowywane do niego jak do przestrzeni trójwymiarowej, uzyskanej przez oddzielenie komponentu wzrokowego od słuchowego i dotykowego, jakiego alfabet fonetyczny miał dokonać na szeroką skalę po wynalezieniu ruchomej czcionki przez Johannesa Gutenberga (por. McLuhan 2001: 84-85, 347-349). Feldmana nie interesował jednak sposób istnienia przedmiotu w czasie, ale przedmiot ,jako czas”, co jego zdaniem ,muzyka, łudzona, że jest liczona w sekundach, zaniedbała" (Feldman 1985: 49, 98; 1988: 3). Jako kompozytor usiłował naprawić to zaniedbanie.

Nie jestem zegarmistrzem - pisał Feldman. Interesuje mnie uchwycenie czasu w jego niepodzielnej egzystencji. To znaczy interesuje mnie jak dzika bestia żyje w dżungli, a nie w zoo. Interesuje mnie jak Czas istnieje zanim położymy na nim nasze łapy, nasze umysły, nasze wyobrażenia (za: Maciejewicz 2000: 17).

Feldmana interesowało trwanie - w sensie, w jakim Dewey określił je jako „wytrwanie” (por. Dewey 1975: 256). Kompozytor zwraca się ku natychmiastowości momentu, nawet gdyby nie miało to sensu w kategoriach przyczyny i skutku (Gagne i Caras 1982: 172). Interesuje go „teraz”, jakie dostrzec można w abstrakcyjnych obrazach zaprzyjaźnionego z nim Barnetta Newmana, dążącego do uchwycenia zdarzeń w ich pierwotnej momentalności. Na płótnach Newmana nie pojawia się czas linearny. Malarz ten miał stwierdzić w swym Prologu do nowej estetyki (1949), że w sztuce interesuje go raczej manipulowanie poczuciem czasu niż przestrzenią i obrazowaniem (por. Wilczyński 1993: 180-181). Feldman postępował podobnie, aby ukazać doświadczalny aspekt teraźniejszości, od którego w dobie renesansu oderwał ludzi zegar mechaniczny, wykorzystujący w funkcji regulatora chodu wahadło lub balans. Zdaniem McLuhana nie doszłoby do tego bez poddania się obciążeniu wzrokowemu, wywołanemu przez druk, pierwotnie nazywany pismem mechanicznym. Czas zegarowy to czas zewnętrzny, obiektywny. Zegar wytworzył wyobrażenie mentalne czasu określające sposób jego postrzegania w społeczeństwach przemysłowych, nazywanych przez Alvina Tofflera społeczeństwami drugiej fali:

Co pewien czas miliony ludzi zgodnie posuwają wskazówki swoich zegarów o godzinę do przodu lub cofają o tyleż. I niezależnie od tego, co nasze wewnętrzne, subiektywne poczucie czasu każe nam myśleć, kiedy czas się wlecze lub zawrotnie pędzi - każda godzina jest teraz po prostu jedną, wszędzie taka samą, standardową godziną sześćdziesięciominutową.

Cywilizacja drugiej fali nie tylko poćwiartowała czas na dokładniejsze i jednakowe kawałki. Umieściła ona także te kawałki na nieskończenie długiej linii prostej biegnącej w jednym kierunku w przeszłość, a w drugim - w przyszłość. Czasowi nadano wymiar linearny (Toffler 1997: 174-175).

Czas linearny, jak odczuwa się go w społeczeństwach industrialnych, przypomina zdaniem Tofflera autostradę prowadzącą z odległej przeszłości przez teraźniejszość do przyszłości (Toffler 1997: 176). Opinię tę podziela Maciejewicz, która odwołując się do teorii czasu muzycznego Johnatana Kramera, utożsamiła linearność czasu muzycznego, dominującą w świecie zachodnim, ze zdolnością do wytworzenia wyobrażenia jego ciągłości, scalonej 
wątkiem przeszłości, teraźniejszości i przyszłości, oraz do ustanowienia pomiędzy nimi silnego związku przyczynowo-skutkowego. Są to czynniki niezbędne dla powstania linearnego kontinuum czasowego, w którym to, co następuje potem, będzie rezultatem czegoś, co wydarzyło się przedtem. Maciejewicz zauważa, że linearność implikuje słuchanie teleologiczne oraz percepcję lewopółkulową (Maciejewicz 2000: 13-14), na co zwracał uwagę również McLuhan. Czas linearny znamionuje zatem ciągłość, będąca cechą przestrzeni realistycznej, opartej na zasadach perspektywy linearnej, a wszelka ciągłość - jak twierdził kanadyjski teoretyk mediów - wyklucza możliwość uczestnictwa (McLuhan 2001: 173, 465).

Znacznie więcej trudności sprawił Maciejewicz opis nielinearności w muzyce jako raczej obcej zachodniemu sposobowi pojmowania czasu. Maciejewicz, tak jak McLuhan, łączy nielinearność z domeną prawej półkuli mózgu. Zauważa też, że czas nielinearny charakteryzuje nierozwojowość oraz zawieszenie przyczynowości. Czas tego rodzaju nie posiada zdolności łączenia przeszłości, teraźniejszości i przyszłości. Jest nieciągły, zatem - zgodnie z założeniami McLuhana - angażujący odbiorcę. Jest to czas, jaki ewokuje muzyka Feldmana, określona przez Maciejewicz jako wręcz antyrozwojowa (por. Maciejewicz 2000: 16), co sam kompozytor potwierdził explicite w wykładzie wygłoszonym w 1984 roku we Frankfurcie: „Nie pracuję w ciągłości. [...] Innymi słowy nie zajmuję się informacją linearną" (Biró 2001: 23).

Maciejewicz zwraca uwagę na jeszcze jedną właściwość czasu nielinearnego - jego zdolność wytwarzania poczucia stasis (Maciejewicz 2000: 14), czego doświadczył chyba każdy ze słuchaczy muzyki Feldmana. Sam kompozytor pisał o tym tak:

[...] stasis, jakie jest wykorzystywane w malarstwie, tradycyjnie nie było częścią muzyki. W muzyce można uzyskać rodzaj unieruchomienia, albo jego złudzenia: które wywołuje magritte'owski świat Satie'go, czy „ruchoma rzeźba” Varese'a. Stopnie stasis, jakie można znaleźć u Rothka albo Gustona, były być może najważniejszym elementem, jaki przeniosłem do swojej muzyki z malarstwa (Feldman 1985: 137).

Już w cyklu Two Intermissions, skomponowanym przez Feldmana w 1950 roku, tok dźwiękowy nie został uporządkowany pod względem metrycznym, pozbawiono go punktu oparcia dla regularnej pulsacji (por. Sadie 2002: 650). Zdecydowaną większość utworów Feldmana z lat 50. i 60., a zwłaszcza jego partytury graficzne z tego okresu, Eco zakwalifikowałby jednak jako dzieła otwarte mieszczące się w kategorii tak zwanych dzieł w ruchu obok Klavierstück XI (1956) Karlheinza Stockhausena czy III Sonaty fortepianowej (1957) Pierre'a Bouleza. Nie da się tego jednak powiedzieć o Madame Press Died Last Week at Ninety z 1970 roku oraz o pozostałych dziełach Feldmana powstałych później, zanotowanych precyzyjnie w formie tradycyjnej partytury - o jednej chronologii, postaci i układzie zdarzeń dźwiękowych. Skłoniło go do tego niezadowolenie z wykonań utworów komponowanych wcześniej:

[...] zawsze czułem, że wykonawcy byli poniekąd precyzyjni co do tego, jak grać dźwięki, lecz nie słuchali siebie. Nie byli też precyzyjni co do pauz. [...] W rzeczywistości, kiedy tego słuchasz, nie masz wrażenia aż takiej komplikacji rytmicznej, jaka jest na papierze. To jest ruchome. Na papierze wygląda to tak, jak gdyby był to rytm. Nie jest. To jest trwanie (Feldman 1985: 232). 
Feldman utożsamia rytm z istnieniem ictusu, wyznaczającego funkcję arsis i thesis oraz ustanawiającego wyrazisty punkt orientacyjny dla percepcji relacji czasowych, przyjmujący postać regularnego akcentu metrycznego. Ictus nadaje status jednostki podstawowej każdej z komórek rytmicznych, wyodrębnionych dzięki jego działaniu jako najmniejsze, zamknięte całości ruchowe. Ictus jest też spoiwem łączącym je w większe całości, pozwalającym na zachowanie ciągłości ruchu na wyższym poziomie syntezy rytmicznej.

Natomiast trwanie - w znaczeniu zaproponowanym przez Feldmana - nie przyjmuje postaci ictusu (nawet tam, gdzie kompozytor stosuje oznaczenia metryczne), umożliwiając manipulację psychologiczną zmysłem przewidywania słuchaczy. Trwanie takie rozluźnia jedność oraz zależność rytmiczną arsis i thesis, pozbawiając ją zdolności tworzenia ciągłości i linearnego ukierunkowania, jednocześnie niwelując element polaryzacji i hierarchii, zawarty w relacji arsis i thesis, ustanowiony na najbardziej elementarnym poziomie strukturalnym (por. Rudziński 1987a: 22-26; Kopstick-Ames 1996: 105). Trwanie feldmanowskie sprzyja więc zaangażowaniu odbiorczemu, o jakim pisał McLuhan, a zarazem jest czynnikiem decentralizującym organizację czasową. Nawet ten aspekt zostaje podporządkowany u Feldmana zasadzie kompozycji all-over, znanej z malarstwa Pollocka, a uznanej przez Cage'a za „sposób rozpraszania uwagi”, w której

istnieje przynajmniej możliwość spoglądania gdzie indziej, a nie tylko tam, gdzie sobie ktoś zażyczył. Możesz więc swobodnie dysponować swoją wolnością niczym artysta; nie w ten sam sposób, ale mimo wszystko twórczo (Cage 1996: 126).

Kompozycja all-over pozwala stosującemu ją artyście uniknąć tworzenia hierarchii strukturalnych, by nie dopuścić do powstania form, w których elementy składowe nie miałyby jednakowego znaczenia i nie byłyby równoważne. W przypadku Feldmana prowadzi to do zminimalizowania, jeśli nie całkowitego zniwelowania, jakiegokolwiek kierunkowego przyciągania i wzajemnego warunkowania się kolejnych momentów utworu (w tym również kierunkowego działania melodyki i harmoniki). Tym samym skutkuje pozbawieniem słuchacza możliwości zogniskowania uwagi, co z kolei - paradoksalnie - umożliwia intensywne skupienie jej na najmniejszym nawet detalu tkaniny dźwiękowej i obserwacji czystego brzmienia (por. York 1996: 147-148).

Feldmana interesowały raczej pasywne właściwości dźwięków: ich wybrzmiewanie i zanikanie. Fazę ataku dźwięku starał się uczynić jak najmniej zauważalną (Beal 2002: 234). Można w tym dopatrywać się analogii ze sposobem, w jaki Pollock traktował farbę, pozwalając jej samodzielnie spłynąć z włosia pędzla bez dotykania płótna i ułożyć się na płaszczyźnie obrazu. Typowych pociągnięć pędzlem zanurzonym $\mathrm{w}$ farbie unikał też Rothko, przedkładając nad nie delikatne muskanie i kapanie, by otworzyć w ten sposób obraz i ukazać jego dotykowo doświadczalną powierzchnię. Jego purystyczna koncepcja malarstwa sprowadzała obraz do farby kładzionej na powierzchni płótna w sposób uwydatniający maksymalnie jego płaskość i dwuwymiarowość (por. Hussakowska-Szyszko 1984: 73-75; Kiepuszewski 2013: 83; Kotula i Krakowski 1973: 268). To właśnie obraz dwuwymiarowy ustanawia zdaniem McLuhana formę tłumiącą wizualność, a w zamian przywraca równowagę wszystkich zmysłów i ich współoddziaływanie, wzmagając przy tym aktywność percepcyjną odbiorcy (McLuhan 2001: 193). 
Dla ustanowienia muzycznej „dwuwymiarowości”, pozbawionej punktów ciężkości i ukierunkowania, a przy tym sprzyjającej zaangażowaniu percepcyjnemu słuchacza, konieczne okazało się więc rozważenie kwestii samej artykulacji, czego zdaniem Feldmana nie brano wcześniej pod uwagę, pomimo odejścia od tonalności:

Rezultatem jest płaszczyzna słuchowa [aural plane], która prawie się nie zmieniła od czasu Beethovena i pod wieloma względami jest prymitywna - tak jak Cézanne sprawia, że postrzegamy przestrzeń renesansową jako prymitywną. [...]

Oto dlaczego być może we własnej muzyce jestem w tak wielkim stopniu uwikłany w wybrzmiewanie każdego dźwięku i usiłuję uczynić fazę jego ataku pozbawioną źródła. Faza ataku dźwięku nie określa jego charakteru. W rzeczywistości to, co słyszymy, jest właściwie fazą ataku, a nie samym dźwiękiem. Niemniej jednak, wybrzmiewanie, ten oddalający się pejzaż, to właśnie określa, gdzie dźwięk istnieje w naszym słyszeniu - oddalając się raczej od nas niż zbliżając. (Feldman 1985: 88-89)

Wybrzmiewanie jest zanikaniem dźwięku w ciszy i takim chce go ukazać Feldman - jako zjawisko efemeryczne, niestabilne i nietrwałe, tymczasowe jak semiotyczny przed-znak. Cecha ta znajduje swe analogie na wyższych poziomach organizacji oraz w dramaturgii kompozycji. Zasługuje ona raczej na miano antydramaturgii, ze względu na swą nierozwojowość i zupełną nieobecność klimaksu, do jakiego mógłby narastać przebieg utworów Feldmana. Kompozytor pozwala im - jak to określił - „umrzeć śmiercią naturalną” (za: Biró 2001: 24). Jest to jeszcze jedna cecha kompozycji all-over, „w której najdrobniejsza część jest próbką tego, co można znaleźć gdzie indziej” (Cage 1996: 126). Podobny sposób myślenia o morfologii dzieła muzycznego reprezentował Edgar Varèse, gdy przenosił cechy usamodzielnionych motywów i komórek interwałowych na całość architektoniczną wyższego rzędu (por. Skowron 1995: 155). Feldman poszedł dalej, rzutując na nią wewnętrzne cechy brzmienia pojedynczych, izolowanych impulsów dźwiękowych, uwypuklonych przez czynnik fakturalny, rodem z twórczości Antona Weberna, o którym mawiał, że jest jego muzycznym ,nieślubnym dzieckiem” (Cadieu 1992: 204).

Nad muzyką Feldmana unosi się też duch Henry'ego Cowella. Od samego początku w twórczości Feldmana występowały klastery, które w latach 60. ubiegłego wieku kompozytor zaczął, jak sam pisał, „otwierać troszeczkę”. Feldman kontynuuje: „A potem, przez te wszystkie lata zupełnie je otworzyłem. To kwestia właściwego zorkiestrowania klasteru w jego różnych postaciach [...]" (Kopstick-Ames 1996: 111).

Dla Feldmana „,barwa dźwięku i rozpiętość są tym samym” (Johnson 1987: 28). Zmiany układu współbrzmień złożonych z ciągów sekund (małych i wielkich), ale też ich przewrotów oraz zwielokrotnień oktawowych - jak rozumiał stworzone na użytek własny pojęcie „klasteru otwartego" - zyskują u niego status działania z zakresu instrumentacji, determinującego jakość tembrową współbrzmień.

Dzieje się tak między innymi we fragmencie muzycznym ze słuchowiska Words and Music oznaczonym przez kompozytora numerem osiem, który dostarcza niezwykle zwięzłego jak na autora kwartetu smyczkowego trwającego sześć godzin - przykładu procedur reprezentatywnych dla jego późnej twórczości. Dość czytelnie przedstawia on relacje, jakie 
w kontekście rozbudowanej obsady oraz zdecydowanie większych rozmiarów dzieła stają się znacznie bardziej złożone, wielopoziomowe i wielorakie. Wymagała tego specyfika tekstu Becketta. Oto co sam Feldman powiedział o komponowaniu muzyki do Words and Music: „Musiałem myśleć szybciej; musiałem pisać szybciej. Musiałem bardziej to skondensować. [...] Potrzebowałem czasu; jednakże tutaj nie miałem go" (Frost 1998: 54).

Materiał dźwiękowy fragmentu muzycznego numer osiem z Words and Music stanowią składniki klasteru: des-es-f-fis-g-as-a-b-ces, nawarstwiane i rozwarstwiane na przestrzeni zaledwie siedemnastu taktów w sposób kontrolowany przez kompozytora, w czym decydującą rolę odgrywa instrumentacja oraz brak synchronizacji czasowej pomiędzy partiami instrumentalnymi. Przy ich pomocy wydzielone zostały cztery warstwy brzmieniowe, pomiędzy które rozdystrybuowane zostają wybrane wysokości dźwięku, realizowane przez: (1) instrumenty smyczkowe, (2) fortepian, (3) wibrafon, (4) flety. Barwa dźwięku zyskuje tym samym funkcję strukturalną, jaką w malarstwie Newmana, Stilla czy Rothki pełnił kolor, albowiem - jak twierdził Feldman - „instrument też jest materiałem” (Feldman 1985: 177). Niewiele dzieliło go pod tym względem od Varèse'a, posługującego się barwą dźwięku tak, jak kubiści posługiwali się barwą farby, chcąc uzyskać właściwe oddalenie od siebie elementów kompozycji obrazu (por. Kamiński 1998: 13). Tembr stawał się w jego rękach czynnikiem separującym elementy kompozycji muzycznej. We fragmencie numer osiem z Words and Music Feldman ufa mu do tego stopnia, że rezygnuje z operowania rejestrami (zwłaszcza skrajnymi), nastawionego na uzyskanie podobnego efektu lub wzmocnienie go. Wykorzystana przestrzeń dźwiękowa nie przekracza tu obszaru mezofonicznego, pomiędzy oktawą wielką (od dźwięku $B$ ) i trzykreślną (do dźwięku g"'). Stopień zagęszczenia fakturalnego powoduje, że współbrzmienia wyodrębnione w wybranej warstwie instrumentalnej krzyżują się ze współbrzmieniami z pozostałych warstw w momentach, gdy dochodzi do ich sprzężeń, wywołując wrażenie dążenia przez muzyków do koordynacji czasowej swych partii, by uzyskać jeden, zwarty agregat brzmieniowy, złożony ze wszystkich dźwięków otwartego klasteru, w jaki sumują się akordy przypisane do poszczególnych warstw. Elementem różnicującym są wyłącznie zastosowane środki wykonawcze oraz desynchronizacja partii instrumentalnych, pozwalające wyodrębnić daną strukturę muzyczną i ukonstytuować jej tożsamość. Jest to jednak tożsamość eteryczna, zagrożona wchłonięciem przez kontekst, $\mathrm{z}$ jakiego ją wyłoniono. Nie jest ona autonomiczna na tyle, by spełnić warunek tak zwanego dobrze ukształtowanego motywu, a więc takiego, którego jednoznaczność i wyrazistość sprawią, że będzie on postrzegany jako rozpoznawalna formuła, trwale zachowująca swą integralność oraz identyczność mimo wielokrotnego użycia w zmiennych kontekstach harmonicznych, fakturalnych czy tembrowych (por. Rudziński 1987: 113). Feldman dostarcza raczej negatywów takich dobrze ukształtowanych i dookreślonych figur muzycznych o precyzyjnie zarysowanym, stabilnym kształcie, traktując je w sposób, jaki zawdzięczał również Beckettowi:

Obecnie sposób, w jaki pracuję - pisał Feldman - polega na tym, zwłaszcza w ciągu ostatnich dwunastu lat, i nie jest on oryginalny. Jest wiele osób, które pracują w ten sposób, ale w innych dziedzinach. Samuel Beckett, nie we wszystkim, co robi, ale w wielu rzeczach, które robi. Chce napisać coś po angielsku, tłumaczy to na francuski, następnie 
thumaczy tę myśl z powrotem na angielski tak, że rozwija tę myśl. I wiem, że nadal tak postępuje. Napisał coś dla mnie w 1977 roku i zabrałem się do tego. Czytam to. Jest w tym coś osobliwego. Nie mogę tego uchwycić. W końcu zauważam, że każdy wers jest faktycznie tą samą myślą, wypowiedzianą w inny sposób (Feldman 1985: 185).

Ekwiwalent tego rodzaju postępowania Becketta kompozytor chciał uzyskać we własnej twórczości:

Więc to, co robię, polega na tym, że dokonuję translacji. Mówię coś w sytuacji wysokościowej, a następnie robię to tam, gdzie jest ona bardziej interwałowa, i podążam za jej sugestiami z powrotem, do innego rodzaju zakresu wysokości - nie do pierwotnego zakresu wysokości, i tak dalej, i tak dalej. Zawsze dokonując retranslacji, by powiedzieć potem: a teraz zróbmy to $\mathrm{z}$ innym rodzajem ogniska. [...]

Myśl wypowiedziana w inny sposób. Często w innym języku. W języku innego rejestru, języku innej barwy. I chcę posłużyć się „różnicowaniem” tych rzeczy, jak widzicie. [...]

Potem zostanie wzięty pod uwagę inny aspekt. Parametry wciąż ulegają fluktuacji. Ognisko nieustannie zmienia swoje położenie. Tak, jakby światło padało tu, następnie tutaj, potem tam (Feldman 1985: 186).

W opisywanym fragmencie muzycznym sytuacja wysokościowa, jak określił ją Feldman, występuje w warstwach: smyczków, fortepianu oraz fletów. Każda z nich zostaje powiązana z jedną z trzech komórek: dwu- (flety), trzy- (instrumenty smyczkowe) lub czterodźwiękową (fortepian), pomiędzy które rozdysponowano cały dostępny materiał dźwiękowy, stanowiący monolit brzmieniowy, z jakiego przy pomocy instrumentacji wyselekcjonowano wybrane klasy wysokości. Skojarzono je w układy dźwiękowe wykazujące pokrewieństwo strukturalne: współbrzmienie powtarzane przez fortepian składa się ze zbioru klas wysokości będącego transpozycyjno-inwersyjną odmianą serii pierwotnej, oznaczonej przez Allena Forte'a symbolem 4-Z15 $(0,1,4,6)$, natomiast współbrzmienia realizowane przez partie smyczków (wersja inwersyjna szeregu $0,1,6)$ oraz fletów $(0,1)$ pozostają z nią w relacji podrzędności, świadczącej o ich pokrewieństwie (por. Jarzębska 2002: 197-204).

Niejednoznaczna jest rola, jaką odgrywa partia wibrafonu, utrzymywana w stanie zawieszenia pomiędzy sytuacjami określonymi przez kompozytora jako wysokościowa i interwałowa. Wibrafon może sprawiać wrażenie instrumentu koloryzującego współbrzmienia występujące w partii fortepianu. Partia wibrafonu zawiera w taktach $1-4$ oraz w takcie 15 tę samą komórkę czterodźwiękową (najpierw w postaci horyzontalnej, a później jako zwarte współbrzmienie) co fortepian, z zachowaniem układu i położenia rejestrowego jej składników. Komórka ta zostaje pozbawiona w takcie 4 i 5 najwyższego ze składników i w tej uszczuplonej, trzydźwiękowej postaci wibrafon transponuje ją w takcie 8 i 10 w dół o odległość septymy małej i seksty małej, zachowując układ interwałowy, nieznacznie zmodyfikowany dopiero $\mathrm{w}$ takcie 11 przez zamianę położeń rejestrowych dwóch ze składników akordu.

Jednak tożsamość współbrzmienia granego przez wibrafon w takcie 8 może być rozpatrywana równolegle jeszcze z innych punktów widzenia: równocześnie zdwaja ona brakujący dźwięk es z partii fortepianu oraz jest zawarta w konturze o rozpiętości septymy wielkiej, 
wyznaczonym przez dźwięki a-as, jakie w tym samym układzie są powtarzane w warstwie fletów o oktawę wyżej. Z kolei akord wyodrębniony przez wibrafon w takcie 10 nadal zachowuje kontur o rozmiarze septymy wielkiej, charakterystyczny dla partii fletów, a jednocześnie składa się z klas wysokości tworzących współbrzmienie grane mniej więcej w tym samym czasie przez instrumenty smyczkowe.

Taka niejednoznaczność, a zarazem jednoczesność relacji (wewnętrznych i zewnętrznych) zachodzących pomiędzy układami dźwiękowymi, przywodząca na myśl koncepcję symultanizmu Varèse'a (por. Kamiński 1998: 14), charakteryzuje nie tylko warstwę realizowaną przez wibrafon, ale również pozostałe warstwy instrumentalne, mimo że na pierwszy rzut oka mogły się one wydać bardziej stabilne. Równoczesność, a zarazem zwrotność związków tego rodzaju uniemożliwia ustalenie i utrwalenie jednej konstelacji elementów o jednej, linearnie zorientowanej chronologii. Tworzą one zdecentralizowaną, rizomatyczną sieć krzyżujących się oraz zachodzących na siebie podobieństw i analogii, dopuszczającą różne sposoby konfiguracji postrzeżeniowej. Relacja figura-tło ulega tu rozmyciu, jak w uproszczonym malarstwie Rothki, gdzie formy, przenikając się, tworzą swoją ramę, a jednocześnie znajdują się wewnątrz niej (por. Cooper 2013: 75) - gdzie pola barwne i ich kontekst utrzymywane są w stanie nierozstrzygalnego napięcia, nie dysponując jedną zasadą determinującą proces percepcyjny:

Figury ulegające takiej fluktuacji dotykają stanów pośrednich naszego postrzegania, na przejściu między dwoma rozpoznaniami. Nie istnieje ścisła determinacja nacechowania danej figury, ponieważ zestaw czynników, jakie musi wziąć pod uwagę aparat spojrzenia w definiowaniu relacji między elementami, otwiera się na alternatywne rozwiązania. Określenie danej jakości wizualnej w procesie oglądu wymaga wzięcia pod uwagę również kontrimpulsów, które przeciwstawiają się pierwszym próbom identyfikacji. Istotna jest zatem wymuszana na naszym widzeniu ciągła modyfikacja stanowiska, która rewiduje już rozpoznane stany rzeczy (Kiepuszewski 2013: 89).

To nie my słuchamy muzyki Feldmana, lecz muzyka Feldmana słucha nas.

\section{Bibliografia}

Beal, A. C. 2002. Time Canvasses: Morton Feldman and The Painters of The New York School. W: J. Leggio, red. Music and Modern Art: 227-245. New York: Routledge.

Beckett, S. 1983. Proust. Przeł. A. Libera i E. Jasińska. Dialog, 4.

Benedetti, M. T. 2002. Cézanne. Życie i twórczość. Warszawa: Wydawnictwo Arkady.

Berbue, M. R. 1998. John Dewey and the Abstract Expressionists. Educational Theory, 2(48): 211-227.

Biró, D. P. 2001. Morton Feldman's Rothko Chapel. Journal of the Third International Conference on Jewish Music. London.

Bland, W. 1980. Morton Feldman. W: S. Sadie, red. The New Grove Dictionary of Music and Musicians: 455-456. London: Macmillan Publishing Co. 
Cadieu, M. 1992. Morton Feldman - Waiting. Przeł. Ch. Villars, H. Mea. Źródło: http://www.cnvill.net/mfcadeng.htm, 19.03.2015. Za: M. Cadieu. A l'ecoute des compositeurs. Paris: Minerve.

Cage, J. 1996. O Robercie Rauschenbergu, artyście i jego dziele. Przeł. J. Jarniewicz. Literatura na Świecie, 1-2: 123-137.

Cooper, H. 2013. Zupa Rothki. Przel. M. Bartelik. W: M. Bartelik, red. Mark Rothko. Obrazy w National Gallery of Art w Waszyngtonie. Warszawa: Muzeum Narodowe w Warszawie.

de Kerckhove, D. 2001. Powłoka Kultury. Przeł. W. Sikorski i P. Nowakowski. Warszawa: Wydawnictwo Mikom.

Dewey, J. 1975. Sztuka jako doświadczenie. Przeł. A. Potocki. Wrocław: Ossolineum.

Eco, U. 1994. Dzieto otwarte. Forma i nieokreśloność w poetykach współczesnych. Przel. J. Gałuszka, L. Eustachiewicz, A. Kreisberg i M. Oleksiuk. Warszawa: Czytelnik.

Esslin, M. 1980. Samuel Beckett and the Art Broadcasting. W: M. Esslin, red. Mediations: Essays on Brecht, Beckett, and the Media. Baton Rouge: Louisiana State University Press.

Esslin, M. 1980. The Theatre of the Absurd. Harrisonburg: R.R. Donnelley and Son Co.

Feldman, M. 1988. Between Categories. Contemporary Music Review, 2: 1-5.

Feldman, M. 1985. Essays. W: W. Zimmerman, red. Essays. Köln: Beginner Press.

Feldman, M. 2015. Introduction to Performance of "For Philip Guston". Źródło: http://library.buffalo.edu/music/special-materials/morton-feldman/pdf/mfnanmf189.pdf, 19.03.2015.

Feldman, M. 2001. Morton Feldman Slee Lecture, November 20, 1972. Baird Hall, University at Buffalo, The State University of New York. Przeł. N. Walker-Smith, red. J. Bewley. Źródło: http://library.buffalo.edu/music/special-materials/mortonfeldman/lectures.html\#slr315, 19.03.2015.

Feldman, M., Morton Feldman Slee Lecture, February 2, 1973. Baird Hall, University at Buffalo, The State University of New York. Przeł. Nicola Walker-Smith, red. J. Bewley. Źródło: http://library.buffalo.edu/music/special-materials/morton-feldman/lectures.html\#slr320, 19.03.2015.

Frost, E. 1998. The Word Man and The Note Man: Morton Feldman on Composing the Music for Samuel Beckett's "Words and Music" in "The Beckett Festival of Radio Plays". W: M. Bryden, red. Samuel Beckett and Music: 47-57. Oxford: Clarendon Press.

Gagne, C. i Caras, T. 1982. Soundpieces: Interview with American Composers. Metuchen: Scarecrow Press.

Glass, P. 1995. Music by Philip Glass. New York: Da Capo Press.

Hussakowska-Szyszko, M. 1984. Spadkobiercy Duchampa? Negacja sztuki w amerykańskim środowisku artystycznym. Kraków: Wydawnictwo Literackie.

Jarzębska, A. 2002. Strawiński. Myśl i muzyka. Kraków: Musica Iagellonica. 
Jarzębska, A. 2002. Z dziejów myśli o muzyce. Wybrane zagadnienia teorii i analizy muzyki tonalnej i posttonalnej. Kraków: Musica Iagellonica.

Johnson, T. 1987. Remembrance. Musik Texte, 12.

Kamiński, P. 1998. Światło, ruch, przestrzeń. Kształtowanie się estetyki twórczej Edgara Varèse w świetle jego własnych wypowiedzi i kontaktów ze środowiskami twórczymi Europy i świata. Monochord. De musica acta, studia et commentari, 19.

Kędzierski, M. 1990. Samuel Beckett. Warszawa: Wiedza Powszechna.

Kędzierski, M. 1996. Widziane i Słyszane. Twórczość Samuela Becketta wobec irytującego dylematu istnienia. Kwartalnik Artystyczny. Kujawy i Pomorze, 4.

Kiepuszewski, Ł. 2013. Zanurzenie w powierzchni. Rothko według Nietzschego i polskie ślady. W: M. Bartelik, red. Mark Rothko. Obrazy w National Gallery of Art w Waszyngtonie. Warszawa: Muzeum Narodowe w Warszawie.

Kopstick-Ames, P. 1996. Piano (1977). W: T. De Lio, red. The Music of Morton Feldman. New York: Excelsior Music.

Kotula, A. i Krakowski, P. 1973. Sztuka Abstrakcyjna. Warszawa: Wydawnictwa Artystyczne i Filmowe.

Kutnik, J. 1997. Gra stów. Muzyka poezji Johna Cage'a. Lublin: Wydawnictwo Uniwersytetu Marii Curie-Skłodowskiej.

Laws, C. 2008. Beckett-Feldman-Johns. W: L. Ben-Zvi, A. Moorjani, red. Beckett at 100 Revolving It All. Oxford, New York: Oxford University Press.

Libera, A. 1995. Wstęp. W: S. Beckett. Dramaty. Wybór. Wrocław: Zakład Narodowy Imienia Ossolińskich.

Libera, A. 1981. „Partia monologu” na tle ostatnich utworów scenicznych Becketta. Literatura na Świecie, 4.

Maciejewicz, D. 1999. „Sujet en procès” w semiotycznej teorii Julii Kristevej a muzyka Mortona Feldmana. Res Facta Nova, 3.

Maciejewicz, D. 2000. Zegary nie zgadzają się ze sobą. Warszawa: Instytut Sztuki Polskiej Akademii Nauk.

Maruszewski, T. 2001. Psychologia poznania. Sposoby rozumienia siebie i świata. Gdańsk: Gdańskie Wydawnictwo Psychologiczne.

McLuhan, M. 2001. Wybór tekstów. Przeł. E. Różalska, J. M. Stokłosa. Poznań: Wydawnictwo Zysk i S-ka.

McLuhan, M. 2004. Zrozumieć media. Przedłużenia człowieka. Przeł. N. Szczucka. Warszawa: Wydawnictwa Naukowo-Techniczne.

Nyman, M. 2011. Muzyka eksperymentalna. Cage i po Cage'u. Przeł. M. Mendyk. Gdańsk: Wydawnictwo słowo/obraz terytoria.

Rosset, B. 1996. „...moje postaci to cienie...” Strony o Samuelu Beketcie. Przeł. M. Kędzierski. Kwartalnik Artystyczny - Kujawy i Pomorze, 3-4. 
Rothko, Ch. 2013. Mark Rothko i Muzyka. Przel. M. Bartelik. W: M. Bartelik, red. Mark Rothko. Obrazy w National Gallery of Art w Waszyngtonie. Warszawa: Muzeum Narodowe w Warszawie.

Rudziński, W. 1987. Nauka o rytmie muzycznym (T. 1 i 2). Kraków: Polskie Wydawnictwo Muzyczne.

Skowron, Z. 1995. Nowa muzyka amerykańska. Kraków: Musica Iagellonica.

Toffler, A. 1997. Trzecia fala. Przeł. E. Woydyłło. Warszawa: Państwowy Instytut Wydawniczy.

Warnaby, J. 1998. Morton Feldman on CD. Tempo, a Quarterly Review of Modern Music, nr 207.

Welsch, W. 2005. Estetyka poza estetyką. O nowa postać estetyki. Przeł. K. Wilkoszewska. Kraków: Universitas.

Wilczyński, M. 1993. Postmodernistyczna wzniosłość: Derrida i Lyotard. W: A. Jamroziakowa, red. Poznańskie Studia z Filozofii i Nauki: Inspiracje postmodernistyczne w humanistyce. Warszawa, Poznań: Wydawnictwo Naukowe PWN.

Wölfflin, H. 1962. Podstawowe pojęcia historii sztuki. Problem rozwoju stylu w sztuce nowożytnej. Przeł. D. Hanulanka. Wrocław: Zakład Narodowy Imienia Ossolińskich.

Wes, Y. 1996. For John Cage. W: T. De Lio, red. The Music of Morton Feldman. New York: Excelsior Music.

\begin{abstract}
The aim of the article is to show the open nature of Morton Feldman's late works despite the traditional form in which they were written. The analysis has been set in a wide context, including music, art and literature as well as philosophy and science.

Keywords: Morton Feldman; open work; transactional model; time in music; nonlinearity in music.
\end{abstract}

